\title{
IMPACT OF PROTOCOL OF CARE REGARDING CHILDHOOD PNEUMONIA ON NURSES' KNOWLEDGE AND PRACTICE
}

\author{
Amina Aboubakr Elsayed Ahmed El Zeiny(a); Prof. Afkar Ragab Mohamed(b);Dr. Nabila \\ Hassan Abed. Ella(c);Dr. Rehab Hani Alkazaz(c)
}

(a) B.Sc, Suez Canal University;(b) Professor of Pediatric Nursing, Faculty of Nursing Cairo University;(c) Lecturer ofPediatric Nursing, Faculty of Nursing, Port Said Uiversity

\begin{abstract}
Pneumonia is an inflammation and consolidation of lung parenchyma. The aim of the current study was to determine the impact of implementing protocol of care for childhood pneumonia on nurses' knowledge and practice. A quasi-experimental study was used and carried out at pediatric wards of El-Nasr, Port SaidGeneral, and Port-Fouad General Hospitals. The subjects were comprised of 44 nurses and 25 children with pneumonia. The data was collected using an interview questionnaire sheet to assess nurses' knowledgeand observational checklists to assess nurses' practice as well asa data sheet of children with pneumonia. The study's results indicated thatmore than half of them had an average knowledge scores level before application of the protocol; but immediately after implementation of the protocol, a vast majority of the studied nurses had good level; meanwhile after 12 weeks (follow up), threequarters of them had good level. Regarding nurses' level of practice(100\%)of the studied nurses had poor level in pre test; while in post test the majority of them (84\%) had good level regarding their level of practice and after 12 weeks as a follow- up 95.5\%of them had average level. The study's results concluded that the designed protocol of care regarding childhood pneumonia had highly statistical significant differences in the studied nurses' knowledge and practice. The study recommended that periodic refreshing training courses should be provided to nurses in order to keep them up to date in knowledge and practice regarding care of childhood pneumonia.
\end{abstract}

KEYWORDS: Childhood pneumonia \& protocol of care for nurses 


\section{INTRODUCTION:}

The health of a growing child is always a matter of great concern, because a healthy child can become a healthy citizen in the future. Children are our future and outmost precious resources. Children's well-being is central to that of society as a whole (The Children's Society, 2012; Oommen \& Vatsa, 2013). Children in Egypt comprise $43.75 \%$ of whole population and children under five years $10.6 \%$ at 2006 (Sherry et al., 2013).The United Nations International Children's Emergency Fund [UNICEF] (2013) define early childhood as the period of a child's life up to five years of age, it's a critical for cognitive, social, emotional and physical development. Events in the first few years of life are formative and play a vital role in shaping social and health outcomes and in building human capital, thereby promoting economic productivity later in life. Pillitteri (2014) added that during childhood, all body systems mature. The respiratory tract continues to mature during childhood. Children have several important differences in respiratory anatomy and physiology thanadults which increase the risk for disease.

Pneumonia is a widespread and common infectious lung disease that causes inflammation, which can lead to reduced oxygenation, shortness of breath, and death. An estimated nearly 1.2 million children younger than 5 year died in 2011 from pneumonia. Most of these deaths occurred in developing countries where access to care is limited and interventions that have improved care in developed countries are scarce(Izadnegahdar et al., 2013).According to National Center for Health Statistics [NCHS] (2013); stated that pneumonia is the sixth leading cause of death in the United States.World Health Organization [WHO] (2014)added that the incidence of pneumonia in Egypt was $11 \%$ of total mortality rate under five years, at the third cause of death after prematurity and congenital anomalies.

Pneumonia occurs due to invasion of the lower respiratory tract by microbes. Inhalation of airborne pathogens, aspiration of gastric and nasopharyngeal flora and spread from other infected sites are the most common routes for microbes to access the lower respiratory tract. The development of pneumonia and its severity is then a balance between bacterial (virulence, inoculum size) and host factors (host defences, e.g. physical, specific and non-specific immune responses)(Loebinger \& Wilson, 2012).

Risk factors of pneumonia, including indoor air pollution, malnutrition, lack of breastfeeding, low maternal education, low socioeconomic status, poor access to care, and concomitant illnesses (Wonodi et al., 2012).Diagnosis of pneumonia is depending firstly on history and physical examination. Child with suspected pneumonia should have a Chest X-Ray (CXR) to 
demonstrate consolidation which leads to accurate diagnosis of pneumonia with laboratory investigation and sputum cultures results (Saad et al., 2014;Marcdante\& Kliegman, 2015).

The treatment of pneumonia depends on its grade, the first line of treatment is antibiotic plus supportive care. Treatment mostly depends on causative agent and according to determine the appropriate for each cases.If child not received specific treatment, inadequate or delayed treatment; the child is immunocompromised. Complications may appear such as pleural effusion, empyema, pneumothorax or lung abscess (Singh \&Aneja, 2011;Ben-Shimol et al., 2014).The vision of the Global Action Plan for Prevention and Control of pneumonia (GAPP) is that every child is protected against pneumonia through a healthy environment, and has access to preventive and treatment measures. Specific goals are to reduce mortality from pneumonia in children less than 5 years of age by $65 \%$ by 2015 compared to 2000 levels; reduce the incidence of severe pneumonia by $25 \%$ in children less than 5 years of age by 2015 compared to 2000 levels (WHO/UNICEF, 2013).

Nursing care of childhood pneumonia is primarily supportive and symptomatic but necessitates thorough respiratory assessment and administration of supplemental oxygen, the child respiratory rate and status, oxygenation. To prevent dehydration, fluids are frequently administered intravenously. Monitor vital signs and oxygen saturation level to assess progress of disease. Child with cough those difficulty handing secretion; require suctioning to maintain patent airway (Hockenberry \& Wilson, 2011). Protocols of care are the descriptions of the steps taken to care for and treat a child. They are sometimes called the integrated care pathway' and are designed to implement national standards. Determine care provision by using the best available evidence if national standards are not available(Natinoal Health Service [NHS], 2008).

\section{Significance of the Study:}

In Egypt, 2011 (42,000) children under-five die as a result of pneumonia. Pneumonia is a relatively inexpensive disease to cure, but the biggest problem is that many of these children die simply due to a lack of awareness of the disease and available preventive measures(Zaazoue, 2011).

\section{AIM DF THE STUIDY:}

The aim of the study was to determine the impact of implementing protocol of care for childhood pneumonia on nurses' knowledge and practice. 


\section{HYPOTHESES}

1. The mean scores of nurses' knowledge will be higher after implementationof protocol of care about childhood pneumonia than before.

2. The mean scores of nurses' practices will be higher after implementationof protocol of care about childhood pneumonia than before.

\section{SUBJECTS AND METHOD:}

\section{Design:}

Aquasi-experimental research design was utilized in the current study

\section{Sample / setting:}

A convenient sample of 44 pediatric nurses and 25 children suffering from pneumoniawere participated in the study.The setting; El-Nasr, Port- Fouad, and Port-Said General Hospitals at Port Said Government.

\section{Tool of the study:}

Data were collected using the following tools:

\section{A Structured Interview Sheet forNurses:}

It were designed by the research investigator after reviewing of the related literatures, it was written in Arabic language and composed of two parts containing open and closed ended questions to assess the following:-

\section{Part (I)}

\section{A. Personal and Professional characteristics data of the studied nurses. \\ B. Data about characteristics of childrensuffering from pneumonia.}

\section{Part (II)}

A. Nurses'Knowledge regarding childhood pneumonia and its interventions.

II. Observation checklists for nurses: were adapted fromBall et al. (2012); Bowden \& Greenberg (2012)and Nettina (2014), certain modifications were done by the research investigator in the adapted checklists to suit the nature of the study.It was used to assess nursing care of child with pneumonia.

The above tools were used before and after protocol of care implementation to assess nurses' actual practice.

\section{- Content Validity of the Tool}

It was ascertained by seven experts in the field of pediatrics and pediatric nursing. Necessary modifications were done according to the experts' opinions.

\section{- Reliability of Tool}


It was held on 4 nurses in pediatric medical wards. Cronbach's alpha coefficient was used to assess the internal consistency of knowledge and its value was (0.87).

\section{- Pilot Study}

A pilot study was carried out on 4 nurses working at pediatric units in El- Nasr General Hospital. The purpose of the pilot study was to test applicability, clarity, relevance and feasibility of study tools and sequence of questionsto maintain consistency. The necessary modifications were done and the final form was developed. The nurses in the pilot study were excluded from the final subjects of the study.

\section{Field Work}

The data were collected fromthe firstof August 2013 to the end ofNovember 2013 the pre test done. Immediatelypost testfrom the firstof December 2013 and follow up test done after 12 weeks from post test at the first of March 2014. The research investigator was available at each studyphase.The research investigator collects the data from one to five days per week; a number of one to five nurses were interviewed per day.Each nurse was individually interviewed to assess their knowledge about pneumonia using structured interview sheet within 20-30 minutes while their nursing care was assessed by using observational checklists during their actual practice, this done before and after protocol of care implentation and after 12 weeks later as follow up to assess nurses knowledge and practice retention.

\section{Ethical consideration:}

Each study subjectshad the freedom to be involved in the study or to withdraw at any time. Parents of the studied children consent was obtained before data collection ensuring complete privacy and total confidentially.

\section{Statistical analysis:}

Data were analyzed with SPSS version 16. The normality of data was first tested with onesample Kolmogorov-Smirnov test. Qualitative data were described using number and percent. Association between categorical variables was tested using Chi-square test. When more than $25 \%$ of the cells have expected count less than 5, Fisher exact test was used. Continuous variables were presented as mean \pm SD (standard deviation). The two groups were compared with Student $\boldsymbol{t}$ test (parametric data). Analysis of Variance (ANOVA of F test) used for comparison of means of more than two groups.

\section{RESULTS:}

Table (1)it indicated that there were highly statistical significant differences in the studied nurses' knowledge in pre, immediately post, and after 12 weeks follows up in relation to signs of infiltration of I.V, methods of oxygen therapy, types of chest physiotherapy and pressure of 
suction machine. While statistical significant differences in the studied nurses' knowledge in pre, immediately post, and after 12 weeks follows up in relation tomodes of transmission and health education.

Figure (1) indicated that $(54.5 \%)$ of the studied nurses had average level of their scores of knowledge in pre test. In post test vast majority of the studied nurses (95.5\%) had good level in their scores of knowledge. As regards nurses' level of knowledge regarding care of childhood pneumonia after 12 weeks asa follow up(75\%) of the studied nurses had good level regarding their scores of knowledge.

It is reveled from figure (2) that (100\%)of the studied nurses had poor level in their level of practice in pre test. While in post test the majority of them $(84 \%)$ had good level regarding their level of practice and after 12 weeks as a follow- up (95.5\%)of them had average level.

Table (2)showed that there were no statistical significant relation between the studied nurses' total knowledge means scores "pre test" scores and their personal and professional characteristics data.

Table (3)Regarding relations between total nurses' practice mean scores " pre test" and personal and professional characteristics data table (5) indicated that there were highly statistical significant relations between the studied nurses' total practice means scores "pre test" in relation to educational level and years of experience with $\mathrm{p}<0.001$. While the same table showed that there were no statistical significant relation between the studied nurses' total practice means scores" pre test" in relation to their age.

Theresultsdemonstrated that a highly statistically significant correlation between the studied nurses' total knowledge mean scores and total practice mean scores with $(\mathrm{p}<0.001)$.

\section{DISCUSSION:}

Pneumonia remains one of the most common causes of mortality in developing countries; it's considered the first cause of death all over the world (WHO, 2013).Dubois et al. (2007) stated that education and training programs for nurses help to investigate both the current practice and educational requirements of nursing staff for continuous updating of knowledge and skills to improve the quality of care.The present study findings have demonstrated that nurses' knowledge about modes of transmission of pneumonia, were improved after application of protocol of care. This result may be related to the effect of shortage of continues instructions which given by infection control units in the hospitals. This result was supported byMohamed (2001) found that more than two-thirds of nurses had poor knowledge level regarding modes of transmission. 
Table (1): Nurses' Knowledge about pneumonia and its intervention in Pre test, immediately Post Test and after 12 weeks Follow up. $(n=44)$.

\begin{tabular}{|c|c|c|c|c|c|c|c|c|}
\hline \multirow[t]{2}{*}{ Knowledge } & \multicolumn{2}{|c|}{ Pretest } & \multicolumn{2}{|c|}{$\begin{array}{c}\text { Immediate } \\
\text { Post test }\end{array}$} & \multicolumn{2}{|c|}{$\begin{array}{l}12 \text { weeks } \\
\text { Follow up }\end{array}$} & \multirow[t]{2}{*}{$\overline{X^{2}}$} & \multirow[t]{2}{*}{$\mathbf{p}$} \\
\hline & No & $\%$ & No & $\%$ & No & $\%$ & & \\
\hline $\begin{array}{l}\text { Modes of transmission } \\
\text { - Complete answer } \\
\text { - Incomplete answer } \\
\text { - Don't know }\end{array}$ & $\begin{array}{c}21 \\
18 \\
5\end{array}$ & $\begin{array}{l}47.7 \\
40.9 \\
11.4\end{array}$ & $\begin{array}{c}29 \\
15 \\
0\end{array}$ & $\begin{array}{c}65.9 \\
34.1 \\
0 \\
\end{array}$ & $\begin{array}{c}27 \\
17 \\
0\end{array}$ & $\begin{array}{c}61.4 \\
38.6 \\
0 \\
\end{array}$ & 11.6 & $\begin{array}{c}0.02 \\
*\end{array}$ \\
\hline $\begin{array}{l}\text { Health education } \\
\text { - Complete answer } \\
\text { - Incomplete answer } \\
\text { - Don't know }\end{array}$ & $\begin{array}{c}14 \\
28 \\
2 \\
\end{array}$ & $\begin{array}{c}31.8 \\
63.6 \\
4.5 \\
\end{array}$ & $\begin{array}{c}28 \\
16 \\
0 \\
\end{array}$ & $\begin{array}{c}63.6 \\
36.4 \\
0 \\
\end{array}$ & $\begin{array}{c}20 \\
24 \\
0\end{array}$ & $\begin{array}{c}45.5 \\
54.5 \\
0 \\
\end{array}$ & 12.1 & $\begin{array}{c}0.017 \\
*\end{array}$ \\
\hline $\begin{array}{l}\text { Signs of infiltration of } \mathbf{I} . \boldsymbol{V} \\
\text { - Complete answer } \\
\text { - Incomplete answer } \\
\text { - Don't know }\end{array}$ & $\begin{array}{c}13 \\
31 \\
0 \\
\end{array}$ & $\begin{array}{c}29.5 \\
70.5 \\
0 \\
\end{array}$ & $\begin{array}{c}28 \\
16 \\
0 \\
\end{array}$ & $\begin{array}{c}63.6 \\
36.4 \\
0 \\
\end{array}$ & $\begin{array}{c}24 \\
20 \\
0 \\
\end{array}$ & $\begin{array}{c}54.5 \\
45.5 \\
0 \\
\end{array}$ & 10.9 & $\begin{array}{l}0.004 \\
* *\end{array}$ \\
\hline $\begin{array}{l}\text { Methods of oxygen therapy } \\
\text {-Complete answer } \\
\text {-Incomplete answer } \\
\text {-Don't know }\end{array}$ & $\begin{array}{c}8 \\
35 \\
1\end{array}$ & $\begin{array}{c}18.2 \\
79.5 \\
2.3\end{array}$ & $\begin{array}{c}33 \\
11 \\
0\end{array}$ & $\begin{array}{c}75 \\
25 \\
0\end{array}$ & $\begin{array}{c}24 \\
19 \\
1\end{array}$ & $\begin{array}{c}54.5 \\
43.2 \\
2.3\end{array}$ & 29.6 & $\begin{array}{l}<0.001 \\
\quad * *\end{array}$ \\
\hline $\begin{array}{l}\text { Types of chest physiotherapy } \\
\text { - Complete answer } \\
\text { - Incomplete answer } \\
\text { - Don't know }\end{array}$ & $\begin{array}{c}2 \\
29 \\
13\end{array}$ & $\begin{array}{l}4.5 \\
65.9 \\
29.5\end{array}$ & $\begin{array}{c}38 \\
6 \\
0\end{array}$ & $\begin{array}{c}86.4 \\
13.6 \\
0\end{array}$ & $\begin{array}{c}29 \\
15 \\
0\end{array}$ & $\begin{array}{c}65.9 \\
34.1 \\
0\end{array}$ & 72.6 & $\begin{array}{c}<0.001 \\
* *\end{array}$ \\
\hline $\begin{array}{l}\text { Pressure of suction machine } \\
\text { - Complete answer } \\
\text { - Incomplete answer } \\
\text { - Don't know }\end{array}$ & $\begin{array}{c}16 \\
0 \\
28\end{array}$ & $\begin{array}{c}36.4 \\
0 \\
63.6\end{array}$ & $\begin{array}{c}32 \\
12 \\
0\end{array}$ & $\begin{array}{c}72.7 \\
27.3 \\
0\end{array}$ & $\begin{array}{c}37 \\
0 \\
7\end{array}$ & $\begin{array}{c}84.1 \\
0 \\
15.9\end{array}$ & 68.9 & $\begin{array}{c}<0.001 \\
* *\end{array}$ \\
\hline
\end{tabular}

$\# * \rightarrow$ significant $p<0.05 \# * * \rightarrow$ highly significant $p<0.001 \# X^{2} \rightarrow$ chi-square test

Fig (1): Nurses' Level of Knowledge Regarding Care of Childhood Pneumonia N (44).

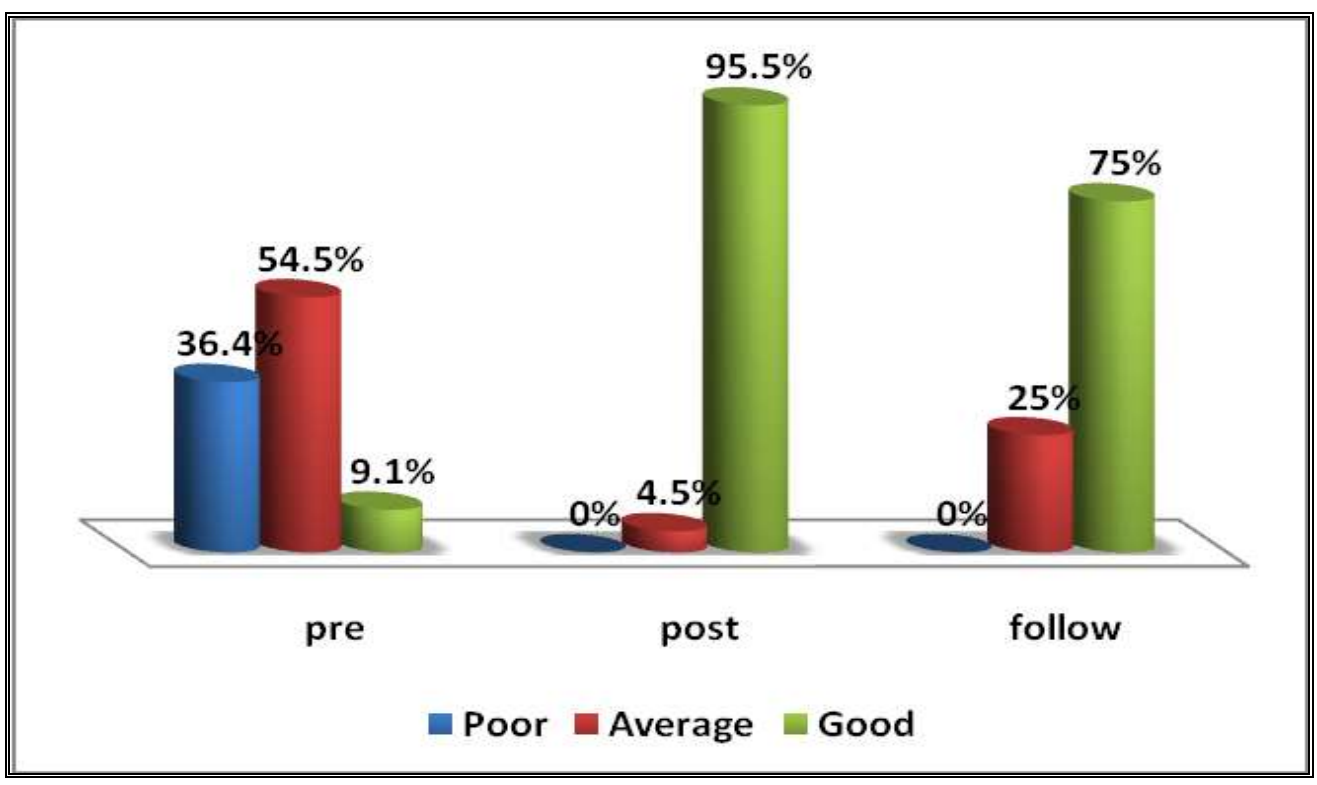


Fig (2)Nurses' Levels of Practice Regarding Childhood Pneumonia.

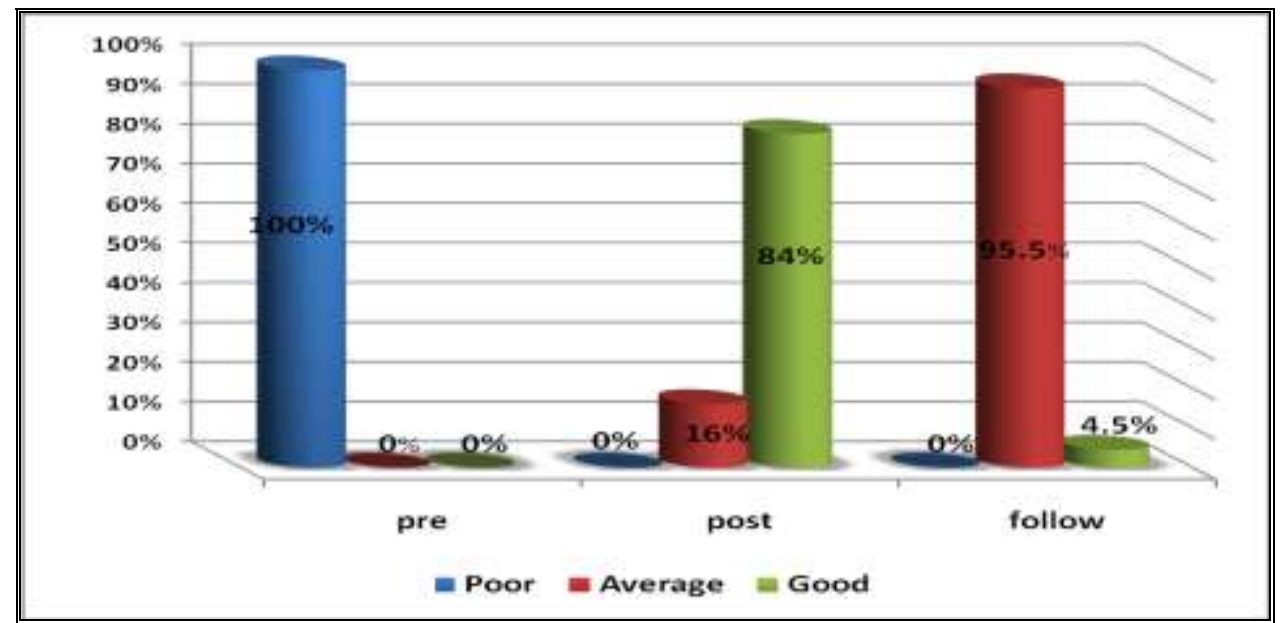

Table (2): Relations between Total Nurses' Knowledge Mean Scores in Pre Test Scores and their Personal and Professional Characteristics Data $(n=44)$.

\begin{tabular}{|c|c|c|c|c|}
\hline \multirow{2}{*}{ Personal and Professional Data } & \multicolumn{2}{|c|}{$\begin{array}{c}\text { Total Knowledge Mean } \\
\text { Scores }\end{array}$} & \multirow{2}{*}{$\begin{array}{l}\text { Test of } \\
\text { sig }\end{array}$} & \multirow{2}{*}{$\mathbf{p}$} \\
\hline & Mean \pm SD & Range & & \\
\hline & & & & A \\
\hline$<20-$ & $51 \pm 7.07$ & $46-56$ & \multirow{3}{*}{$\mathrm{F}=1.18$} & \multirow{3}{*}{$\begin{array}{l}0.32 \\
\text { N.S }\end{array}$} \\
\hline$-20-<30$ & $55.14 \pm 6.78$ & $43-57$ & & \\
\hline$->30$ & $51 \pm 3.08$ & $48-56$ & & \\
\hline & & & \multicolumn{2}{|c|}{ Educational leve } \\
\hline Secondary School of Nursing- & $53.83 \pm 6.21$ & $43-68$ & \multirow{3}{*}{$\mathrm{F}=2.49$} & \multirow{3}{*}{$\begin{array}{l}0.096 \\
\text { N.S }\end{array}$} \\
\hline Technical Institute of Nursing- & $53.33 \pm 5.55$ & $46-66$ & & \\
\hline Bachelor's Degree in Nursing- & $60.4 \pm 8.38$ & $54-75$ & & \\
\hline & & & \multicolumn{2}{|c|}{ Years of experienc } \\
\hline$-<5$ & $58.25 \pm 12.12$ & $46-75$ & \multirow{3}{*}{$\mathrm{F}=1.05$} & \multirow{3}{*}{$\begin{array}{l}0.36 \\
\text { N.S }\end{array}$} \\
\hline$-5-<10$ & $54.55 \pm 6.29$ & $43-68$ & & \\
\hline$->10$ & $52.56 \pm 3.94$ & $46-58$ & & \\
\hline
\end{tabular}

$\# N . S \rightarrow$ not significant $p>0.05 \quad \# F \rightarrow$ ANOVA 
Table (3): Relations between Total Nurses' Practice Mean Scores in Pre Test and their Personal and Professional Characteristics Data $(n=44)$.

\begin{tabular}{|c|c|c|c|c|}
\hline \multirow{2}{*}{ Personal and Professional Data } & \multicolumn{2}{|c|}{ Total Practice Mean Scores } & \multirow{2}{*}{$\begin{array}{r}\text { Test of } \\
\text { sig }\end{array}$} & \multirow{2}{*}{$\mathbf{p}$} \\
\hline & Mean \pm SD & Range & & \\
\hline & & & & Age \\
\hline$<20-$ & $106.5 \pm 7.78$ & $101-112$ & \multirow{3}{*}{$\mathrm{F}=0.83$} & \multirow{3}{*}{$\begin{array}{l}0.44 \\
\text { N.S }\end{array}$} \\
\hline $20-<30-$ & $96.16 \pm 12.14$ & $80-126$ & & \\
\hline$>30-$ & $94.2 \pm 8.56$ & $84-106$ & & \\
\hline \multicolumn{5}{|c|}{ Educational level } \\
\hline - Secondary School of Nursing & $91.83 \pm 8.61$ & $80-113$ & \multirow{3}{*}{$F=22.75$} & \multirow{3}{*}{$\begin{array}{c}<0.001 \\
* *\end{array}$} \\
\hline - Technical Institute of Nursing & $99.67 \pm 7.81$ & $91-115$ & & \\
\hline - Bachelor's Degree in Nursing & $118.2 \pm 6.22$ & $111-126$ & & \\
\hline & & & \multicolumn{2}{|c|}{ Years of experience } \\
\hline$-<5$ & $113.5 \pm 9.33$ & $101-122$ & \multirow{3}{*}{$\mathrm{F}=6.43$} & \multirow{3}{*}{$\begin{array}{c}0.004 \\
* *\end{array}$} \\
\hline$-5-<10$ & $95.68 \pm 10.95$ & $80-126$ & & \\
\hline$->10$ & $91.44 \pm 8.85$ & $80-106$ & & \\
\hline
\end{tabular}

$\# N . S \rightarrow$ not significant $p>0.05$

\#** $\rightarrow$ highly significant $p<0.001 \# F \rightarrow A N O V A$

\section{Discussion:}

Concerning the studied nurses' knowledge about health education given to parents about childhood pneumonia, the present study showed that more than half of the studied nurses had incomplete answers about health education, but after protocol of care application more than half of the studied nurses had complete answers. This result was comparablewith,El-Ghadban (2010) who found that the majority of the nurses had incomplete knowledge regarding health education of children with pneumonia. This may be attributed to lacks of continues protocol of care, which supports the nurses by needed information.

Regarding the studied nurses' knowledge about signs of infiltration of I.Vtherapy the current study showed that three-quarters of the studied nurses had incomplete answers before protocol of care conduction; meanwhile after protocol of care, two-thirds of them had complete answers. According to Roach \& Ford (2008), nurses should inspect the site of injection or needle site for signs of infiltration which including: redness, edema and pain at site of infusion.Regarding to the studied nurses' knowledge about methods of oxygen therapy, the present study revealed that more than three-quarters of the studied nurses had incomplete answers, but after protocol of care application three-quarters of them had complete answers. This may be due to nurses known the applicable methods in wards not all type may be used and they didn't updated their knowledge regarding oxygen methods. This result goes in the same direction with Solberg et al. (2011) in studying nursing assessment during oxygen 
administration in ventilated infants, who found that the nurses' assessments when adjusting oxygen levels

Regarding the studied nurses' knowledge regarding types of Chest Physiotherapy(CPT) there were statistical significant different was found between pre test and post test. this may be due to most of nurses didn't know types of CPT and only did percussion and didn't do postural drainage, vibration, breathing and cough exercise. These findings supported by Saeed (2012) who found that the majority of the nurses had poor knowledge about CPT.

As regards the studied nurses' knowledge about pressure of suction machine value, the present study showed that less than two-thirds of the studied nurses didn't know the accurate pressure of suction machine value, but after protocol of care implementation more than twothirds of them had complete answers about pressure of suction.In this respect,Hadian and Sabet (2013) emphasized on the importance of suctioning to maintain the airway clear to prevent stasis of pulmonary secretion.

Regarding the studied nurses' total knowledge mean scores the present study revealed that high statistical significant difference was found between pre test and post test. According to Carol (2009), the formal training courses plays an important role in enhancing and updating nurses' knowledge and practice beside improving the care given to children with pneumonia, in pediatric unite. That reflects massive need for conducting training courses with multiple efforts to provide high quality care to children with pneumonia. This finding was congruent with,AbouAhmed (2013)who reported that the training programs in nursing would increase professional knowledge, which will result in improved child care.

Concerning the studied nurses total practice mean scores, the results of the present study revealed that there were a highly statistical significant differences in the post and follow up tests with $(\mathrm{p}<0.001)$. In the same field, Johnson(2007) studied the evaluation of educational intervention for staff on head of the bed elevation in pediatric intensive care unit, and detected that after following the utilization of standardized educational interventions the nurses' practice improved. Therefore, continuous reinforcement would necessary to achieve higher level of professionalism and provide standardized child care. 
As regards the relationships between nurses' knowledge and practices and their age and years of experience in pediatric ward, the present study findings revealed no association of statistical significance different was found. This may be attributed to that older nurse with more years experience was accustomed to do routine work, which they considered to be just a manual work to be performed every day without updating their knowledge. Finding of the present study was congruent with $\boldsymbol{E L}$-Ezaby(2004), who found there were no statistical significant relations between nurses' knowledge and practice and their age and years of experience.

Concerning comparison between total mean scores of the studied nurses' practices according to their educational level in pre, post, and follow up test; the results of the present study revealed that there were a statistical significant differences between diploma and bachelor degree nurses.These results were supported by a study of Ahmed(2008), who found that the total mean scores of bachelor degree nurses' practices were higher than diploma nurses. This could be related to bachelor degree nurses more familiar with medical terminology utilized in the unit.

Regarding studies reveled that there were a highly statistical significant correlation between the studied nurses' knowledge and practices in pre, post and follow up protocol of care implementation $(\mathrm{p}<0.001)$. These findings reflected the strong relations between knowledge and practices, as well the effectiveness of nursing care protocol in improving nurses' practice. The results of the present study support the proposed study hypotheses. Such finding was consistent with Tolentino-DelosReyes et al. (2007); Mize (2009) who mentioned that educational interventions could positively affect nurses' practices.

\section{CONCLUSION:}

The study concluded that mean score of nurses' knowledge was higher after exposure to protocol of care about pneumonia than before. The mean score of nurses' practices was higher after exposure to protocol of care about pneumonia than before.

\section{RECOMMENDATIONS:}

1. Updating guidelines of protocols of care about childhood pneumonia must be generalized.

2. Protocol of care should be applied regularly specially for newly coming nurses to consolidate this important part of practice. 
3. Multidisciplinary team approaches should be directed to enhance prevention of childhood pneumonia.

4. Pediatric nurses as a health educator can participate in many health associations to raise mother and child awareness toward pneumonia.

\section{REFERENCES}

Abou Ahmed, H. (2013). Effect of Protocol of Nursing Care on Children with Ventilator Associated Pneumonia. Unpublished Doctoral Thesis, Faculty of Nursing, Menofia University. pp. 98-107.

Ahmed, A. (2008). Quality of Nursing Interventions while Managing Children Receiving Mechanical, Unpublished Master Thesis, Faculty of Nursing, Menofia University. pp. 88-96.

Ben-Shimol, S., Levy-Litan, V., Falup-Pecurariu, O., \& Greenberg, D. (2014). Evidence for Short Duration of Antibiotic Treatment for Non-severe Community Acquired pneumonia (CAP) in Children - are we there yet? A Systematic Review of Randomized Controlled Trials. Pneumonia.17 (4):16-23.

Carol, C. (2009). Application and Development of Pediatric Nursing Guidelines, Journal of Pediatric Nursing. 88(26):81-8.

Dubois, H., Padovano, G., \& Stew, G. (2007). Improving International Nurse Training: An American Italian case study. Int Nurs Rev. 53(2):110-6.

El-Ghadban, F. (2010). Assessment of Nursing Care Given to Children with Pneumonia. Unpublished Master Thesis, Faculty of Nursing, Ain Shames University. pp. 64-86.

Hadian, Z., \& Sabet, R. (2013).The Effect of Endotracheal Tube Suctioning Education of Nurses on Decreasing Pain in Premature Neonates. Iran J Pediatr.23 (3): 340-4.

Hockenberry, M., \& Wilson, D. (2011). Wong's Nursing Care of Infants And Children $\left(9^{\text {th }}\right.$ Ed.). Canada: Elsevier Mosby. Chapter 32 - The Child with Respiratory Dysfunction. pp. 1244-7. 
Izadnegahdar, R., Cohen, A., Klugman, K., \& Qazi, S. (2013). Childhood Pneumonia in Developing Countries. The Lancet Respiratory Medicine. 1(7):574-84

Johnson, R. (2007). Evaluation of Educational Intervention for Staff on Head of the Bed Elevation in Pediatric Intensive Care Unit. A Dissertation Submitted in Partial Fulfillment of Requirements for the Degree of Philosophy in The College of Nursing at the University Of Central Florida Orlando. Florida: USA. pp. 196.

Loebinger, M., \& Wilson, R. (2012). Pneumonia. Medicine, 40(6):329-334.

Marcdante, K., \& Kliegman, R. (2015). Nelson Essentials of Pediatrics $7^{\text {th }}$ Ed. Philadelphia: Saunders an imprint of Elsevier Inc.Chapter 110: Pneumonia. pp. 512-4.

Mize, M. (2009). Ventilator Associated Pneumonia in Pediatric Setting; Barriers to Head of Bed Elevation. Unpublished Doctorate of Nursing Practice, School of Nursing, University of Virginia, USA. pp. 98.

Mohamed, S. (2001). Knowledge and Practices of Nurses Dealing with Pneumonic Children in Sharkia hospitals. Unpublished Master Thesis, Faculty of Nursing, Al Zagazeg University. pp. 182.

Natinoal Health Service [NHS]. (2008). Protocol Based Care. Available at http://www.institute.nhs.uk Accessed at 17/10/2013, 8 AM.

National Center for Health Statistics (NCHS). (2013). Health, United States, with Special Feature on Emergency Care. Washington: USA.

Oommen, A., \& Vatsa, M. (2013). Mothers Awareness Regarding Danger Signs of Neonatal Illnesses at a Selected Hospital in Trivandrum. International Journal of Nursing Care. $1(2): 152-66$.

Pillitteri, A. (2014). Maternal and Child Health Nursing ( $7^{\text {th }}$ Ed.). China: Lippincott Williams \&Wilkins. Chapter 40 Nursing Care of a Family When a Child Has a Respiratory Disorder. pp. $1152-8$. 
Roach, S., \& Ford, S. (2008). Introductory Clinical Pharmacology ( $8^{\text {th }}$ Ed.) London: Wolters Kluwer \& Lippincott William. Chapter 2: Administration of Drugs. pp. 19-32.

Saad, K., Mohamed, S., \& Metwalley, K. (2014). Recurrent/Persistent Pneumonia among Children in Upper Egypt. Mediterr J Hematol Infect Dis. 6(1): e2014024. DOI: 10.4084/MJHID.2014.024.

Saeed, L. (2012). Impact of An Intervention Program for Nurses about Nursing Care of Children with Pneumonia at al Maknemir University hospital \& Shendi teaching hospital. Unpublished PhD in Pediatric Nursing, Post Graduate University, Soudan. pp. 99.

Sherry, L., Murphy, S., Jiaquan Xu, D., Kenneth, D., Kochanek, A., \& Division of Vital Statistics. (2013). Deaths: Final Data for 2010. National Vital Statistics Reports (NVSS). 61(4):1-118.

Singh, V. \& Aneja, S. (2011). Pneumonia Management in the Developing World. Paediatric Respiratory Reviews. 12(1):52-9.

Solberg, M., Hansen, T., \& Bjørk, I. (2011).Nursing Assessment during Oxygen Administration in Ventilated Preterm Infants. Acta Padiatrica. 100:193-7.

The Children's Society. (2012). The Good Childhood Report 2012: A review of our Children's Well-being. Available at http://www.childrenssociety.org.uk Accessed in 15/12/2013, 6 PM.

Tolentino-DelosReyes, A., Ruppert, S., \& Shiao, S. (2007). Evidence-Based Practice: Use of the Ventilator Bundle to Prevent Ventilator-Associated Pneumonia. American Journal of Critical Care. 16 (1):20-7.

United Nations Children's Fund [UNICEF]. (2013). Levels and Trends in Child Mortality: Report 2013. Available at http://www.childinfo.org, Accessed at 09/01/2014, 4 AM.

United Nations Children's Fund [UNICEF]. (2013). Levels and Trends in Child Mortality: Report 2013. Available at http://www.childinfo.org/files/Child_Mortality_Report_2013.pdf, Accessed at 09/01/2014, 4 AM. pp. 4-27. 
Wonodi, C., Deloria-Knoll, M., Feikin, D., DeLuca, A., Driscoll, A., et al. (2012). Evaluation of Risk Factors for Severe Pneumonia in Children: The Pneumonia Etiology Research for Child Health Study. Clinical Infectious Diseases. 54(S2):S124-S131.

World Health Organization [WHO]. (2014). World Heath Statistics 2014. Available at http://apps.who.int, Accessed at 15/05/2014, 2 AM.

World Health Organization/The United Nations Children's Fund [WHO/UNICEF]. (2013). Ending Preventable Child death from Pneumonia and Diarrhea by 2025 the integrating global action plan for pneumonia and diarrhea. Geneva: WHO publications. Accessed at 27/01/2014, 10. PM.

Zaazoue, M. (2011). Pneumonia. Available at http://www.NoPneumonia.com . Accessed in $15 \backslash 6 \backslash 2014$. 


\section{تأثثير بـروتـوكول الرعـايـة التمريضيـة المقدمـة للأطفــال المصابين بالإلتهاب الرئوي على معلومات وممارسات الممرضات}

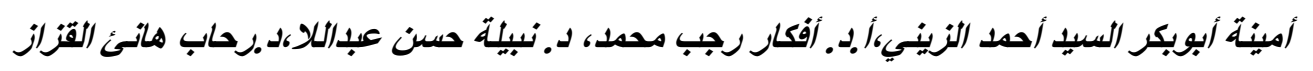

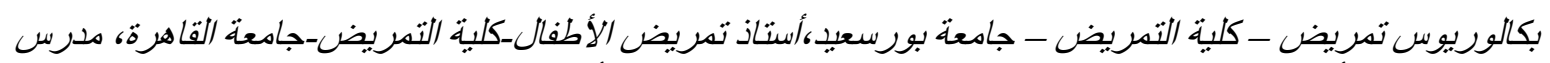

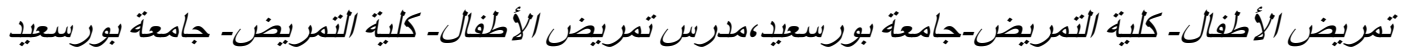

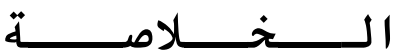

إن الإلتهاب الرئوي هو شكل من أشكال العدوى التنفسية الحسادة التى تصيب الرئتين وتؤثر على الحويصـلات الهو ائية حيث تمـلأ بـالإفر از ات التى تحد من عملية التنفس. إذ تهدف هذة الدر اسـة إلى إعداد وتنفيذ بروتوكول

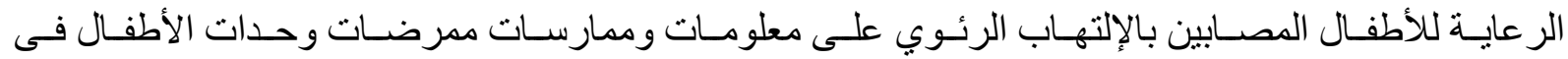
المستشفياتالحكومية وتقييم مدى تأثثيره.وقد أجريت هذه الدراسـة شبة التجريبيـة في أقسـام الأطفـال بمستشـفيات بورسعيد. وتتألف العينة مـن 44 ممرضـة و 25 طفلاً. وقد تم جمع البيانات بإستخدام ورقـة إستبيان مقابلة لتقييم معلومات الممرضات و إستمارة ملاحظة أدائهن قبل وبعد البروتوكول. وقد أشـارت نتائج الدراسـة إلى أن منوسط أعمار الممرضات كان 24.8 عام، وكان مستوى أكثر من نصف الممرضـات "متوسطاً" نسبةً إلى معلومـاتهن وذللك قبل تطبيق البروتوكول؛ ولكن بعد تطبيق البروتوكول مباثرة كانت الغالبية العظمى من الممرضـات جيدي المستوى؛ إلا أنه بعد ما طبق البروتوكول بإثنى عشر أسبو عاً، أصبح ثناثتة أرباعهن جيدي المستوي. أمسا بالنسبة إلى مستوى أدائهن فقد كان كل الممرضـات ضعيفى المستوى وذلك قبل تطبيق البروتوكول؛ في حين أنه بعد تطبيق البروتوكول مباثرة أصبحت الغالبية العظمي منهن جيدي المستوى؛ إلا أنه بعد مـا طبق البروتوكول بـإثنى عشر أسبو عاً، أصبحت الغالبية العظمى من الممرضات متوسطي المستوى. ولخصت نتـائج هذه الدراسـة أنه كان هناك فروق ذات دلالة إحصائية فى معلومـات و أداء الممرضـات قبل وبعد تطبيق البروتوكول. وقد أوصت هذة

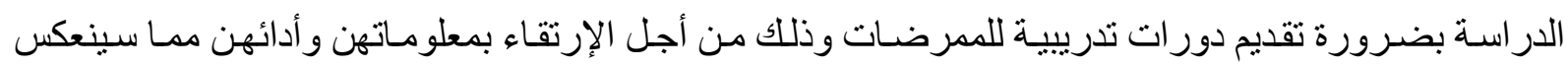
بصورة إيجابية على الرعاية التمريضية وبالتالى على صحة الأطفال. الكلمات الدالة المرشدة:الإلتهاب الرئوى، بروتوكول الرعاية التمريضية. 